NBER WORKING PAPER SERIES

\title{
NON-MONETARY EXCHANGE WITHIN FIRMS AND INDUSTRY
}

\author{
Canice Prendergast \\ Lars Stole
}

Working Paper 5765

\section{NATIONAL BUREAU OF ECONOMIC RESEARCH 1050 Massachusetts Avenue \\ Cambridge, MA 02138}

September 1996

This paper has been prepared for the 1996 Industry Economics Conference in Canberra, Australia, July 4-5, 1996 sponsored by the Productivity Commission and the Centre for Economic Policy Research at the Australian National University; it represents a shortened version of a lengthier survey, Prendergast and Stole [1996a], also prepared for the Conference. We are grateful to Kent Daniel, Chip Heath and participants at the University of Chicago GSB brown bag lunch seminar for helpful comments on portions of this research. We also appreciate financial support from a National Science Foundation Presidential Faculty Fellowship, the Sloan Foundation, the Australian National University and the Productivity Commission. All errors are our own. This paper is part of NBER's research program in Labor Studies. Any opinions expressed are those of the authors and not those of the National Bureau of Economic Research.

(C) 1996 by Canice Prendergast and Lars Stole. All rights reserved. Short sections of text, not to exceed two paragraphs, may be quoted without explicit permission provided that full credit, including $(\mathrm{C}$ notice, is given to the source. 
NBER Working Paper 5765

September 1996

\title{
NON-MONETARY EXCHANGE WITHIN FIRMS AND INDUSTRY
}

\begin{abstract}
This paper considers why non-monetary means of exchange, such as barter and the reciprocation of favors, are chosen by firms despite the usual benefits of monetary transactions. We consider the chosen means of exchange when both monetary and non-monetary exchange mechanisms are available. We illustrate three potential reasons for the emergence of non-monetary trade. First, a willingness to barter may reveal information that cannot be revealed solely through monetary trade. Second, non-monetary trade may constrain the ability of agents to engage in inefficient rent-seeking activities. Finally, non-monetary trade improves the ability of agents to impose trade sanctions on those who act dishonestly. We consider a number of applications of each of these ideas.
\end{abstract}

Canice Prendergast

Graduate School of Business

University of Chicago

1101 East 58th Street

Chicago, IL 60637

and NBER

fac_cp@gsbacd.uchicago.edu
Lars Stole

Graduate School of Business University of Chicago 1101 East 58th Street

Chicago, IL 60637 


\section{Introduction}

Firms often use means of exchange which are non-monetary, settling debts through some sort of contemporaneous barter arrangement or promise of future repayment-in-kind rather than by money. This preference for non-monetary exchange occurs despite standard economic logic on the virtues of money, which has the advantage of achieving a double coincidence of wants (Jevon's [1875]). The purpose of this paper is to discuss why firms and their employees use such non-monetary means of exchange. ${ }^{1}$

Let us begin by listing the range of trades which we consider. First, considerable trade occurs as a direct contractible swap of goods, where good $A$ is exchanged either contemporaneously for good $B$ or a promise of good $B$ in the future. The inefficiencies inherent in such barter arrangements are well documented in the economics literature but such exchanges are nevertheless widespread. Tho International Reciprocal Trade Association [1996] has estimated that the number of North Anerican companies that barter goods either through exchanges or trading companies has increased approximately from 160.000 in 1986 to 380,000 in 1995, and the total dollar value of such bartered exchange was $\$ 8.46$ billion dollars in the US in $1995 .^{2}$ Note also that such domestic barter is largely voluntary anch emerges in absence of market restrictions. Additionally, the phenomenon known as comturtracle in the international trade literature in which imports are exchanged for exports is "phially significant. Although data are difficult to come by, conservative estimates place the amount of intrinational countertrade at a minimum of 10 percent of world trade volume. ${ }^{3}$ Finally, surely (11' of the most important forms of trade that is not compensated by money payments is where indivichuals do voluntary favors for one another even though it would be feasible to offer monetary pilyul'nts for their completion. For example, in many firms trade between individuals or divisions i.: frepuently carried out through an elaborate system of reciprocated favors, relying on the goodwill of the tracling parties. ${ }^{4}$

Oul objective is to consider some of the economic underpinnings of such trades. As such, we

\footnotetext{
${ }^{1}$ In other work, we consider the effects of non-monetary exchange on relationships between individuals in social settings; see Prendergast and Stole [1992,1996c]. For the most part, the theories considered in these papers do not directly relate to trades between or within firms.

'Such data almost surely represent only the tip of the iceberg as many firms barter in the absence of intermediaries. Furthermore, many trades are bundled such as with the practice of 'business reciprocity' in which firms require their suppliers to buy some of their output, usually in addition to money payments.

${ }^{3}$ See Ellingsen and Stole [1996] and sources cited therein.

${ }^{4}$ To quote Weitzman [1974: 478-9]: "The allocation of resources within private companies (not to mention governmental or nonprofit organizations) is almost never controlled by setting administered transfer prices on commodities and letting self-interested profit maximization do the rest. The price system as an allocator of internal resources does not pass the market test."
} 
see this essay as the start of a broader investigation designed to understand the optimal means of exchange in the economy. In describing the reasons for non-monetary trade, we exclude a few obvious reasons why agents would prefer to transact in non-monetary units. First, in some circumstances nonmonetary trade is more efficient than monetary trade because of the costs of contracting explicitly with money. For example, employees are routinely given minor job perks such as free local phone calls during breaks in addition to their wages. The most likely explanation is that such perks would have been explicitly purchased with money by almost all employees if a monetary payment were required, so the firm finds it simpler to offer them as part of a standard employee package with a slightly lower wage. Another reason for non-monetary trade which we exclude from our study is the cost of coordination and delay which would emerge if a firm used a decentralized price-based market system to allocate resources rather using its centralized authority. ${ }^{5}$ In such an internal "command economy" setting, non-monetary exchange minimizes transactions costs, but in a rather direct way, and so are ignored in our study. Finally, in some circumstances, agents simply don't have money to trade, so that some form of non-monetary trade is technologically efficient. None of our analysis will rely on such liquidity constraints.

We have organized the paper around three themes which provide economic reasons why firms may prefer to exchange through goods and services rather than money, despite the obvious deadweight loss from the possible absence of double coincidence of wants.

\section{Theme 1: Non-Monetary Trade Reveals Information Not Conveyed By Mon- etary Trade}

Our first theme, explored in Section 2, illustrates that a willingness to barter may serve to reveal (or conceal) information in a way that cannot occur with purely monetary trade. We begin in section 2.1 by noting that barter may act as a means of secret price cuts when it is difficult or illegal to offer discounts. Therefore, barter may be a means of concealing information about prices. Second, Section 2.2 addresses the role of reciprocal trade analogous to product bundling, for which Adams and Yellen [1976] and McAfee, McMillan and Whinston [1989] have illustrated that a monopolist may raise profits by offering bundles of goods at price discounts in addition to pricing goods individually. In this subsection, barter (through bundled trades) reduces the aggregate uncertainty over a trading partner's surplus in a way that increases firm profits. Third, we show that barter exchanges can act as

\footnotetext{
${ }^{5}$ See Bolton and Farrell [1990] and Milgrom and Roberts [1992, ch. 4] for such arguments.
} 
a means of price discrimination. Section 2.3 describes how barter may indeed succeed in segmenting the market. Finally, a common form of trade agreement between developed and developing countries is where the developing country buys technology from a developed country, but only on condition that the developed country buys back output. Such trades are called buy-backs. Section 2.4 provides a simple interpretation of these arrangements where a willingness to barter reveals information about the quality of inputs.

\section{Theme 2: Non-Monetary Trade May Constrain Inefficient Rent-Seeking}

Our second theme in understanding an attraction of non-monetary barter is that is may restrict the ability of agents to rent-seek. Section 3.1 draws on Ellingsen and Stole [1996], where it is argued that barter may restrict firms form causing monopoly pricing distortions. This arises because the crudeness of barter may paradoxically increase trades, which may more than offset the usual disadvantages of barter. We conclude the paper in Section 3.2 by showing that non-monetary transfers nay restrict rent-seeking by reducing inefficient plays for power. In particular, a recent paper by Rajan and Zingales [1995] notes that a division may choose not to invest on projects if it means that money goes to other divisions, which can be used to harm the its interests. As a result, a division may wish to tie trades to consumption of assets that are non-threatening.

\section{Theme 3: Non-Monetary Trade Improves Trading Sanctions}

Oill final theme follows from the observation that many trades are hard to verify and must be self-enforcing. often through the threat of exclusion from future trade in the event that an agent acts clishonestly. We begin in Section 4, by considering the role of reciprocity of favors of various goods. We consider, for example, whether a firm should allow its agents to trade money between themselves in lieu of services provided. We show that firms may prefer to ban monetary transfers because if some trades are monetized, it reduces the costs of acting dishonestly on other dimensions. The reason for this is that if money is available, an individual or division that acts inefficiently to maximize its short-run gain at the expense of its trading partner can no longer be credibly excluded from all future trading activity. Therefore, trading sanctions are reduced by the existence of money.

Sanctions in relationships can be provided not only by exclusion from the relationship but also by possibly destroying bonds which the agents have put up. Section 4.2 addresses how non-monetary bonds can aid the development of relationships, once again by affecting credible trade sanctions. 
Consider a situation where an individual would like to join an organization or trading relationship and is willing to pay to do so. What can he offer to gain admission? Our central point here is that the only credible currency is likely to be non-monetary because cash hostages are too tempting to consume.

\section{Non-Monetary Exchange Reveals Information}

A useful property of trading goods for money is the informativeness of the resulting prices. Not surprisingly, non-monetary exchange has different informational consequences for trade. In the subsections which follow, we characterize four central sub-themes regarding non-monetary exchange and the resulting information which is communicated.

\subsection{Barter to Conceal Effective Prices}

It is generally more difficult to discern transaction prices with barter than from monetary exchanges. Barter transactions differ from monetary exchange in that they reveal only relative prices and not absolute prices. A market observer, for example, may have difficulty verifying the effective absolute price being cliarged by a firm if the good received in kind is substantially differentiated so that no accurate market price exists. As such, barter is an attractive alternative to a firm that wishes to secretly lower its effective price without detection.

A well-known pricing employed by firms with market power and heterogeneous consumers is thirddegree price discrimination, in which such firms offer a lower price to groups with high elasticities of demancl. A possible requirement for the effective practice of third-degree price discrimination may be the secrecy of the price discounts when the law forbids price discrimination ${ }^{6}$ or when high-paying groups would otherwise have recourse (e.g., because of MFN agreements or the increased likelihood of arbitrage). Barter may allow for such secret price discounting. Caves [1974] has argued that bilateral international trade agreements serve this purpose ${ }^{\top}$ Later work by Caves and Marin [1992] makes a similar argument that countertrade can be used to third-degree price discriminate. They

\footnotetext{
${ }^{6}$ In the United States, for example, price discrimination is illegal under the Robinson-Patman Act whenever its effect is to lessen competition.

${ }^{7}$ Unfortunately, he does not spell out the precise reasons for a need to implement the price reductions via barter rather than explicitly. "Why such a vehicle [bilateral trade agreement] is chosen becomes and important but secondary question. (Footnote: Some writers on business reciprocity have raised the question of why barter agreements should be used when the discriminating monopolist can maximize by simply rigging the money price of any product in which he has the requisite market power.)" Caves [1974, p. 23]
} 
find strong empirical evidence that developing countries and centrally planned economies receive discounted terms of trade through such transactions, as would be predicted by this theory.

Another frequently given motivation for barter and business reciprocity (where buyers require sellers to purchase some goods from them) is to evade price regulation and cartel price fixing. Indeed, Stigler [1969, p. 52] has argued, that reciprocity is "important chiefly where prices are fixed by the state or a cartel." As an example of this argument, Bork [1978, p. 376] suggests that in the Northern Pacific Railroad $v$. United States legal case, the reason for barter was to evade price regulation. In order to avoid ICC rate regulation, the railroad may have offered rate reductions to potential shippers through bargain land prices in exchange for requirements that shipments take place over the railroad's line. Similarly, Banks [1985] notes that barter was probably used as a way of cheating on OPEC cartel agreements in 1984 by some member countries, as 10-20 percent of OPEC"s oil was bartered in that year while the demand for oil was declining and there was a lag in the cartel's adjustment. Other examples where barter may have been used to cheat on price-fixing amee(ments include Jamaica's barter trades while a member of the International Bauxite Association and sercral international commodity agreements (including rubber, cocoa and coffee) (Banlis [195.j]). In aldition, Marin [1990] provides some weak empirical evidence that countries with cartel undulus (rij) tend to enter into countertrade agreements with higher compensation ratios (and therefore pusilsly lower effective relative prices) than countries without such membership. ${ }^{8}$

\subsection{Barter to Reduce Aggregate Uncertainty}

Hunlling wo separate exchanges may afford a firm with the ability to extract additional surplus from its laading partner and thereby raise the total profits earned on the combined markets. ${ }^{9}$ Our argume'nl is inlalogous to the standard argument for product bundling by a monopolist serving two markets. Recall that such a firm can reduce the aggregate uncertainty regarding a consumer's expectecl surplus by bundling two exchanges together in some mixed form, thereby effectively ex-

\footnotetext{
${ }^{4} W_{1}$ do not directly address the welfare implications of such trade. However, Caves [1974] suggests that while the evidence supports price discrimination in international countertrade agreements, no such support can be found in domestic business reciprocity relationships. In the latter, firms typically do not seek out trading partners which seem to have higher elasticities of demand, nor is there and attempt to engage in or prevent the arbitrage which one might otherwise suspect. As a consequence, Caves concludes that the price reductions which occur are probably competitive, in accord with the views of Bork [1978] and Stigler [1969].

9 This idea is not novel and has been made in many other areas of industrial economics. For example, the literature on tying agreements and product market bundling is full of such examples. Indeed, Bork's [1978, ch. 19] discusses tying arrangements and business reciprocity agreements interchangeably. See Tirole [1988] and Carlton and Perloff [1994] for general discussions of the literature. Adams and Yellen [1976] and McAfee, McMillan and Whinston [1989] discuss the theoretical returns to a monopolist from product bundling.
} 
tracting more of the consumer's surplus. Such a result is immediate when there exists correlation between the agent's valuations of consumption on market 1 and on market 2 , as demonstrated by Adams and Yellen [1976]. Furthermore, the result remains with much weaker conditions, including independently distributed valuations as shown by McAfee, McMillan and Whinston [1989].

It is straightforward to extend this argument to the use of barter, by simple relabelling of the exchanges. Suppose that there is trade in two goods between two parties where each party produces one of the goods. Further assume that one firm has all of the bargaining power and is uncertain about both the other firm's costs of production and its valuation of consumption. Then the firm with bargaining power will find it profitable to design the terms of trade to include discounts for two-way trades (i.e., barter) in order to extract more of its trading partner's surplus. The resulting problem is formally identical to the standard bundling case, but where there is both monopoly and monopsony power (rather than monopoly power over the two goods), though now "bundling" takes the form of barter as the goods are exchanged in a mixed-barter agreement.

These benefits of bundling suggest that the documented extent of reciprocity - for instance, among the firms that Sloan [1961] studied, almost half sold more than 10 percent of their output to suppliers - may be due to such monopoly/monopsony bundling arrangements. Moreover, market power is only a requirement in one of the two markets for bundling to be possibly effective, making the argument more plausible. ${ }^{10}$

\subsection{Barter to Reveal Willingness-to-Pay: Self-selection among Marketplaces ${ }^{11}$}

A large and growing amount of goods and services is bartered through intermediated exchanges in Nortlı America. Figures from the International Reciprocal Trade Association (IRTA) indicate that approximately $\$ 8.5$ billion in goods and services were exchanged in 1995 , of which $\$ 1.25$ billion were through local retail trade exchanges. Such barter transactions have grown at a rate of 10.7 percent in recent years. At last count, more than 500 such exchanges were operating in the United States with approximately 380,000 firms participating as active traders. ${ }^{12}$ Moreover, given the explosive growth in internet use and the recent introduction of online barter exchanges, these numbers are

\footnotetext{
${ }^{10}$ For example, it has been argued that in the 1930's IBM used its tying relationship - tying leasing of machines (in which it had market power) to purchases of punch cards (in which it did not) - in order to more effectively extract consumer surplus on the monopoly market by metering usage. Although IBM did not use its monopoly in one market to obtain a monopoly in another (as has been sometimes incorrectly argued), it did use its presence on one market (computer punch cards) in order to improve its monopoly profits on the other. See Bork [1978] for a discussion.

${ }^{11}$ Ideas contained in this subsection are developed more thoroughly in Prendergast and Stole [1996b].

${ }^{12}$ IRTA [1996] and Kiplinger's Personal Finance, February 1996 (Roha and Schulhof [1996, p. 103]).
} 
expected to rise further.

The barter networks trade a great diversity of goods and services. Some examples include rental cars, hotel rooms, office equipment, business services, printing, and vehicle maintenance. The exchanges are largely self regulated, although the IRTA provides industry standards for IRTAmember barter networks. The typical barter exchange charges 10-15 percent per transaction as well as an annual membership fee of $\$ 100-\$ 600$ and possibly a monthly maintenance fee of $\$ 6$ - $\$ 30$. Transaction prices within the exchange are (in theory at least) identical to outside retail prices, except that the transactions take place in barter scrip. ${ }^{13}$

The fundamental question which we address here is what function do barter exchanges serve? One immediate answer is that they are apparently another market opportunity for business and so it is not surprising that so many businesses participate. This does not, however, explain why barter scrip is used as a means of exchange rather than hard convertible currency. Instead, consider two reasons which are given for the success of barter: (1) "it eases the squeeze on cash flow that often playnes small businesses", and (2) it allows a firm to "unload excess inventory and fill unused production time." (Roha and Schulhof [1996, p. 104]). ${ }^{14}$ These elements are play a crucial role in the story we present below.

Thr busic idea we present is that because barter exchanges have non-convertible currency, the liuk of a doulshe coinciclence of wants becomes more likely and so only firms with a low opportunity (os of production (e.g., excess inventories, etc.) will find enough value to justify barter. In addition, if there is positive correlation between cost of production and the value of other goods (e.g., cash flow problens ancl excess inventories are positively correlated), these firms will have more highly-elastic deminuls. In sucls a case. trade diversion is less important as many of these firms would not have purchased at retail prices in any event. Thus, the self-selection of firms to participate in barter exchanges generates increased trades, albeit with an otherwise inferior means of exchange.

A Simple Model of Barter Networks: Let $\phi$ be the probability that a barterer satisfies his demand on the barter market. Alternatively, $\phi<1$ could represent a delay in finding the appropriate good or an expectation of lower quality from a less-than-ideal product. Then $\phi v$ represents the expected value of barter consumption given that the value of his ideal good is $v \in[\underline{v}, \bar{v}]$. As a

\footnotetext{
${ }^{13}$ There is apparently some tension for members to post barter prices which exceed their outside retail price. Some exchanges police for price gouging with expulsion resulting for evidence of such behavior. (Roha and Schulhof [1996, p. 104]).

${ }^{14}$ See also IRTA [1996] for similar statements.
} 
reference point, $\phi=1$ in our cash market, in which all firms participate. We refer to $1-\phi$ as the barter leakage due to a potential lack of a double coincidence of wants.

A cost to bartering one's wares is that a customer who would have normally purchased on the monetary market may instead substitute his trade on the barter market. We let $\alpha$ denote the endogenous probability of such a trade diversion. Finally, let $\pi(c)$ represent a typical firm's expected profit per potential customer as a function of the firm's underlying marginal cost, $c \in[\underline{c}, \bar{c}]$, and let $p \in[\underline{v}, \bar{v}]$ be the external monopoly price for a typical good, where $p \geq \bar{c}$. Thus, the net gain of participating on both the barter exchange and the traditional monetary markets versus participating only on the latter is given by

$$
\Phi=[\phi v-c-\alpha \pi(c)]-\max \{v-p, 0\}
$$

To proceed, we shall put some additional structure on the model to reveal sufficient ingredients for barter to arise as a means of revealing a willingness to pay. Most importantly, we suppose that there is positive correlation between a firm's valuation for one good, $v$, and its cost of producing another. c. As discussed in section 2.2, this can be motivated by cash-flow considerations and excess inventories which seem prominent in the industry descriptions of the firms that barter. For simplicity, consider perfect positive correlation between cost and value in the following form:

$$
v-\mathrm{E}[v] \equiv \gamma(c-\mathrm{E}[c])
$$

In addition, we make three further assumptions: $v>c$, which implies that a double coincidence of wants exists for all market participants; $\phi \underline{v}>\underline{c}$, which is equivalent to assuming that, absent trade diversion, the lowest valuation firm prefers to utilize the barter exchange; and $1>\gamma \phi$, which implies, that the value of the barter exchange to a firm with $v<p$ (in the absence of trade diversion, $\alpha=0$ ) is cleclining as a firm's cost and valuation increase. Straightforward calculations show that the value of barter for an otherwise non-purchasing firm (ignoring trade diversion) equals zero precisely at

$$
v^{*} \equiv \frac{\underline{v}-\gamma \underline{\underline{c}}}{1-\gamma \phi}>0
$$

where the inequality follows from our assumptions. Importantly, if $\phi=1$ (so that the barter exchange is as efficient as the cash-market exchange), then no trade diversion $(\alpha=0)$ implies that $\Phi>0$ for 
all $v \in[\underline{v}, \bar{v}]$; that is, every firm will wish to barter if trade diversion is absent. ${ }^{15}$

The following result forms the main result of this subsection and is easily derived given the preceding model. ${ }^{16}$

\section{Result: Suppose that $p>v^{*}$, Then there exists a Nash equilibrium in which firms with valuations $v \leq v^{*}$ utilize the barter exchange and no trade diversion occurs (i.e., $\alpha=0$ ).}

As a consequence, barter will be used by all firms with low enough valuations (and costs), while high valuation firms will use the 'money' market.

Example: A simple numerical example illustrates the barter equilibrium. Suppose that $\phi=\frac{3}{4}$, $\gamma=1, \imath$ is uniformly distributed on $[10,30]$, and average unit costs are $\mathrm{E}[c]=15$. With these parameter choices, $v^{*}=20 . \Phi(v)$ is graphed below, assuming an external monopoly price of $p=25$.

Note that this example illustrates that those with high and low valuations trade in equilibrium, though those with low valuations only receive welfare of $\phi v$ from the good. Note also that those with valuations between 25 and 30 do not trade while those below do so, The reason for this is that the costs and valuations are correlated so that those with low valuations also have low costs, making them desiralsle candidates for barter. Those with somewhat higher valuations also have higher costs, and so they do not trade.

\subsection{Barter to Reveal Information About The Quality Of Inputs}

In rems of its neasured size, the most important form of non-monetary trade is countertrade. This section directly addresses two types of countertrade. First, in a typical buy-back countertrade, an exporter sells plant or industrial equipment in exchange for some cash and a promise to buy back a specified amount of output produced using the exported capital inputs. Counterpurchase countertrades are similar to buy backs except that the secondary purchases are not output related to the initial purchases. ${ }^{17}$ Our objective here is to provide some insights into these practices.

\footnotetext{
${ }^{15}$ If $\phi=1$ and $\alpha=0$, then $\Phi=v-c-\max \{v-p, 0\} \geq p-\bar{c} \geq 0$.

${ }^{16}$ To prove the result, suppose that $\alpha=0$ and no trade diversion occurs. It is sufficient to demonstrate that (1) $\Phi$ is decreasing in $v$ (and hence $c$ ), (2) $\Phi>0$ at $v=\underline{v}$, and (3) $\Phi=0$ at $v=v^{*}$. In such a case, because $v^{*}<p$ by hypothesis, $\alpha=0$ as assumed, and the outcome is a Nash equilibrium. Condition (1) is easily demonstrated by substituting $v$ for $c$ using the assumption of perfect correlation, and then differentiating; (2) is true by assumption; (3) is implied by the assumption that $p>v^{*}$.

${ }^{17}$ Studies vary considerably as to the magnitude of each form of countertrade. A survey by the National Foreign Trade Council of 122 U.S. firms indicates that 9 percent were buy backs, and 55 percent counterpurchases. (See
} 
Countertrade Buy-backs as Signals of High Quality. A buy-back contract is a particular form of countertrade in which a firm (typically from a developed country) sells plant or production equipment to another firm (typically in a centrally-planned economy or an LDC) in exchange for money and an agreement to purchase some portion of the output produced from the initially transferred capital for a fixed price. For example, Mirus and Yeung [1986] document a buy-back agreement between Volkswagen and the former East Germany in which Volkswagen agreed to deliver a complete engine production plant (capable of manufacturing 286,000 engines per year) and East Germany agreed to deliver 100,000 engines per year after the plant became functional.

The question we address is why it is economically meaningful to condition current sales on future buy-backs? One explanation has been frequently argued by economists - a buy-back agreement is made in response to concerns by the purchasing firm that the capital or plant delivered is possibly not of high quality or efficiency (adverse selection), or that the supplying firm will fail to exert sufficient effort in solving the numerous technical problems which typically arise when bringing a plant on line (moral hazard). ${ }^{18}$ The response to this asymmetry in information at the contract signing stage is to give a stake to the selling firm in the plant's successful operation. One route is through foreign direct investment (either through vertical integration or a joint venture) which would give the supplying firm a direct stalie in the plant's operation. Barring the feasibility of such contracts, buy-backs form all alt crllative second-best solution. By requiring the supplying firm to purchase a fixed quantity of out put back from the new plant, the purchaser of the plant has some assurance that the capital sold is reasonably effective (not a lemon) and that the supplying firm will make efforts to get the plant functional (no moral hazard). ${ }^{19}$

This argument for buy-backs suggests that buy-back contracts should be observed when alternative forms of organization such as foreign direct investment are not available and there is considerable uncertainty regarding the value of the underlying capital offered. With this hypothesis in mind, Hennart and Anderson [1993] collected data on 592 countertrade transactions as reported in Countertrade

Bussard [1987].) A related survey by Hennart [1989] of all transactions reported in Countertrade Outlook from mid 1983 to 1986 reveals that the percents are 13 percent buy backs and 51 percent counterpurchase.

${ }^{18}$ Verbal arguments that buy-backs can solve contractual difficulties due to private information by the supplier of plants and capital is found in Kogut [1986], Mirus-Yeung [1986], Hennart [1989], and Hennart and Anderson [1993].

${ }^{19}$ There are also examples of arrangements similar to buy-back transactions which occur outside of international trade. Masten and Snyder [1993] reconsider the famous United Shoe Machinery Corporation antitrust case which was decided in 1954 by the U.S. Supreme Court In that case, United Shoe Corporation used a buy-back-style arrangement in supplying its shoe machines, requiring in some cases that lease payments to United Shoe depended upon flows of output from the shoe-making machines. Masten and Snyder argue that such an arrangernent was useful for aligning United Shoes incentives with those of the shoe companies without requiring direct ownership. Of course, United Shoe was able to write compensation contracts directly on efficiency variables such as shoe machine output flow, unlike partners in our stylized countertrade story who were assumed unable to contract on quality. 
Outlook from April 1983 to December 1986. They find a statistically significant positive relationship between the level of countertrade within a country and limits on foreign direct investment. They also find a positive relationship between levels of countertrade and a country's perceived political risks which is also consistent with buy-backs being used when alternatives such as direct investment are difficult or costly.

A Conceptual Aside Though this form of countertrade is often put forward as the archetypical example of noll-monetary trade, we feel that the resource allocation arising from countertrade would be little clifferent if it were unbundled into contracts written purely in monetary terms. In essence, this contract is little different from a standard agency contract, where an agent gets paid a share of output as a function of the effort he exerts. With supplier contracts of the type studied above, in many cases they can be decoupled and monetized. When the good produced in a commodity, such as stcel. there is little need to transfer the good itself: all that is necessary is that the supplier of the techolugy gets the monetary equivalent of the value of the goods in the contract. In this sense, these trades sec'un like they can be monetized more easily than others in the paper.

Countertrade Counterpurchases to Guarantee Quality. A counterpurchase arrangement is a comutertritle anreement in which future shipments of consumer goods are provided as compensation for the initial supply of goods. Although similar to buy-backs in many ways, counterpurchase is differcut in that the return flow of goods is not related to the initial transaction. As a consequence, tlæ "linkiagr" which supplied the single-crossing property in buy-backs is not clearly present. Marin ind Silnitzer [1995] argue, however, that such a linkage does exist via financial constraints. In their paper. the intial exporting firm (from a cleveloped country in the West) is assumed to have the ability ro provicle uncontractible high- or low-quality goods (as in our previous buy-back model). It is Pareto efficient for the high-quality goods to be supplied. The importing firm (from a centrally-planned economy or LDC) does not have the marketing resources to market effectively its own consumer goods in the West, and so there are gains from trade in this dimension as well. Suppose, however, that the importing firm has private (non-monetary) benefits from exporting its own consumer goods abroad. If it lad cash, it would gladly pay the Western firm to market the goods (which the Western firm can do at no cost), but it is further assumed that the firm is cash constrained. It is therefore possible that the Western firm may decide to provide high quality rather than low quality in a counterpurchase agreement, because if it cheats on quality, the importing firm cannot afford to pay 
the Western firm to market its goods (which would have yielded even greater surplus to the Western firm). Thus, the two transactions are optimally tied. ${ }^{20}$

\section{Non-Monetary Exchange Constrains Inefficient Rent-seeking}

\subsection{Barter to Restrict Monopoly Power}

Money has two features that typically affect the level of trade. First, it is a general claim on goods which makes it a desirable means of exchange. By contrast, barter requires a double coincidence of wants which is the standard argument against its use. Second, money is highly divisible, so that it is easy to fine-tune a demand to exactly the required level. On the other hand, barter goods may not be easily divisible without substantial loss in utility. For instance, there is little point in trading for the odd pages of a book. Similarly, there is little purpose in a dentist bartering to drill a patient's tooth unless the filling is also provided. The purpose of this section, adapted from Ellingseı and Stole [1996], is to show that such indivisibilities may provide an important advantage of barter over monetary transactions because the crudeness of barter implies a reduction in monopoly demands. However, it must be emphasized that whatever benefits accrue from barter can only arise if monetary trade is banned: it will not the case that agents will voluntarily barter when money tracles are possible.

Assume that there are two divisions in a firm who have demands for a single unit of output produced by the other division. For instance, each division may be considering hiring an employee from the other. Suppose that each division's value for the other's product is a random variable $v_{i}$ and each firm has a random cost of production, $c_{i}$. With marginal-cost pricing, the first-best arises where trade occurs on product $i$ if and only if $v_{i}>c_{i}$. With bilateral monopoly pricing, each division chooses its price to extract rents in the usual fashion, with prices above marginal costs, $p_{i}>c_{i}$.

Consider instead the outcome of a game in which the agents can no longer trade the goods for

\footnotetext{
${ }^{20}$ Marin and Schnitzer [1995] additionally predict that financial constraints are a necessary condition for the attractiveness of counterpurchases, and so an interaction of debt ratios and contractual hazards should have predictive power. To the extent that an additional contractual hazard is the possible default on debt repayments by the trading firm exporting consumer goods for marketing, we might expect a similar correlation between counterpurchase and debt ratios based on the specific investment theory. They provide empirical evidence which is consistent with these theories. In their sample of 230 countertrade contracts by firms producing or located in Austria, they estimate logit and OLS regression models on the decision to counterpurchase or to barter as a function of whether the initial export to the LDC or Eastern European firm was manufacturing plant or machinery (as a measure of potential contractual hazards), the log of debt-to-GNP ratio for the LDC/Eastern European country, and an interaction of the debt ratio and the export type. The interaction term is always significant and positive, as is the class of export which is consistent with the theories.
} 
money. Instead, they can only barter the goods at a relative price of 1 , since each division only has unit demand. When evaluating whether or not to agree to barter, each firm considers its own valuation and costs, and is willing to barter if and only if $v_{j} \geq c_{i}$. This has one obvious cost: that trade can only occur when each person's valuation exceeds its costs. This is the standard cost of barter, where trade only arises with double coincidence of wants. However, it also erodes the monopoly power of both sides as barter is a far cruder device for monopolists to manipulate in bilateral markets. This is the benefit of barter. The relative benefits of barter over monetary trade can be seen in the figures below.

These figures compare three regimes: marginal cost pricing (a benchmark), monopoly pricing with money, and barter. The dark shaded areas measure those cases where trade occurs in both directions. while the lightly shaded areas measure one-way trade (which is obviously impossible in the ("itse of barter). The trade-off between barter and money pricing is then a comparison of the tricles in the sladed areas: barter has the advantage of eliminating monopoly power, but at the cost of recuiring double coincidence of wants.

Remark: Ellingsen and Stole [1996] show that the introduction of barter opportunities to a world wh' 'noney trade is also possible has no effect on trade, even if barter is socially efficient. The ratom for this is that only a buyer who would be willing to purchase in the first place accepts a bartel agreement, thus eliminating barter trades in equilibrium. The advantages of barter can only arise if there is a principal who can ban money trades, as it is important to restrict the 'market oprion for each division. To see the importance of such mandating, Carter and Gagne [1988] report thint in 1084 countertrade was mandated in some form by 88 countries, and the current number probalbly runs into three figures. Out of the total volume of countertrade, an informed estimate is that around half is mandated.

\subsection{Non-Monetary Exchange to Constrain "Power"}

The idea that competing groups within an organization may choose between spending scarce resources on increasing production or on rent-seeking is well known. The resource allocation tradeoffs facing such groups and the resulting welfare consequences have been well documented (see Skaperdas [1992], Hirshleifer [1995], Rajan and Zingales [1995], and sources cited therein). An interesting point 
made by Rajan and Zingales [1995], however, is that the presence of returns from accumulating and exercising power by groups constrains the set of efficient trades which would otherwise be made. In short, inefficient power activities are normal goods.

As an illustration, suppose that group $B$ has a productive decision available which can increase group A's profit at very little cost to group B. Normally, we would expect group A to offer a Coasian "bribe" to group B to obtain the requisite production. But if group B has high marginal returns to power (compared to other productive activities), group A can expect B to mis-use the transfer and spend it on power accumulation, which may render the net trade unattractive for $\mathrm{A}$. The result is that some otherwise-efficient activities do not occur. An example consistent with such phenomena is Yale University's recent refusal of a $\$ 20$ million gift earmarked specifically for a course of studies in Western Civilization. The argument of Rajan and Zingales is that such money would have been used by the Department to garner additional power (most likely through many more endowed chairs and their resulting faculty votes in University matters) which arguably would have negative effects on the University as a whole.

The relevance of this power-playing inefficiency to our own study is that non-monetary exchanges may serve to reduce the inefficient consumption of power. In short, means of exchange other than money may have less of an income effect on power. If a means of exchange exists which transfers utility without simultaneously providing an option for increased power, some efficient exchanges may be restored. Thus, if the gift to Yale was in the form of a new building or a library addition for the Department. inefficient power playing would have been prevented and the gift may have been more palatable to the administration.

\section{Non-Monetary Exchange Improves Trading Sanctions}

\subsection{Non-monetary Exchange and Dynamic Reciprocity}

It goes without saying that a huge amount of trade within firms occurs through the reciprocal exchange of favors. Colleagues routinely help one another, reading their papers, dealing with their clients, forgiving late delivery of goods, and so on, usually with no immediate repayment. Instead, repayment occurs through the reciprocal offering of a favor sometime in the future when it is needed. It is our contention here that firms deliberately choose not to monetize some trades that they could monetize, either by allowing agents to trade or by explicitly putting prices on trades through transfer pricing. 


\subsubsection{A Simple Illustrative Model of Reciprocal Exchange}

Consider two individuals (divisions, employees, etc.) who interact over time, potentially providing inputs to each other's respective projects. Each party to the relationship has two potential projects which may arise during any period of time, where the execution of the project requires help from the other party. The firm that the divisions belong to must make a decision whether to allow monetary transfers between the two divisions. We will denote one project as "noncontractible" and use the $n$ subscript, and we will denote the other project as "contractible" using the $k$ subscript. By contractible, we mean simply that if money transfers can be used, a simultaneous exchange of production in return for money is contractible. For instance, one division may need an employee from the other. A reasonable transfer price here would be his wage plus some portion of the surplus value of the employee to the offering division. Money combined with contractability is therefore necessary and sufficient for a once-off legally enforceable trade. On the other hand, an exchange of money for the execution of the non-contractible project exchange is not legally enforceable and must be self-enforceable. For instance, suppose that one division asks the other to treat one of their main clients well. For obvious moral hazard reasons, the division may choose to renege on its promise to the client. If there is no reliable measure of the client's happiness with the division's behavior, such services are largely non-contractible and can only be enforced through the goodwill of all the parties involved.

Let $l\left(q_{i}\right) \equiv q_{1}-c\left(q_{2}\right)$ denote the welfare created from the trade of good $i$. When project $i$ arises for incliviclual $A$ and $q_{i}$ units of services or goods are supplied by division $B$ for $A$ 's use, a surplus of $q_{i}$ is generated for division $A$ at a cost of $c\left(q_{i}\right)$ which is borne by $B$; the reverse is true when project $i$ becomes available for division $B$. Divisions cannot satisfy their own needs, and are assumed to be residual claimants for their output. For simplicity, we assume $c\left(q_{i}\right)=\frac{1}{2} q_{i}^{2}$ and consider the arrival of projects to be a random process with project $i$ arriving during a short period of time, $d t$, with probability $\lambda_{i} d t$ (technically, projects arrive according to a Poisson process). This latter assumption implies that a double static coincidence of wants (the simultaneous arrival of two projects, one for each individual, during the same small interval of time) occurs with insignificant probability. We assume that each division has a discount rate of $r$, where $\delta$ is the corresponding discount factor, $\delta \equiv \frac{1}{1+r} \in(0,1)$.

It is assumed that the firm cannot write sophisticated contracts with its divisions. Instead, its only choice in this section is to decide whether the divisions should be allowed to transfer money between themselves. If money transfers are allowed, they are free to choose any transfer mechanism 
that they like.

\subsubsection{The Effect of Monetizing Exchange}

We consider two scenarios. The first is where money transfers are banned and so the issue of contractability is irrelevant: trade can only be accomplished through credible but unenforceable promises of future reciprocation. We then compare this to a situation in which the firm allows the divisions to contract between themselves using money. We find that depending upon the discount factor, such monetization can either be a blessing or a curse.

Exchange without Money. Here, the divisions enforce reciprocal trades through the threat of dissolution of the partnership. Assume that quantities $q_{k}$ and $q_{n}$ are traded in equilibrium. Then if one division requires $q_{i}$, the relevant incentive compatibility constraint is that the other is willing to provide it, which requires that

$$
-c\left(q_{i}\right)+V\left(q_{n}, q_{k}\right) \geq 0
$$

where $V\left(q_{n}, q_{k}\right) \equiv \frac{1}{r}\left[\lambda_{k} v\left(q_{k}\right)+\lambda_{n} v\left(q_{n}\right)\right]$ is the present value of the relationship to each division in equilibrium. With these these constraints, equilibrium trades can be characterized by two regions. For large enough $\delta$, neither constraint binds at the first best level of trade, which is given by $q^{e f f}=1$. The first luest level of trade is enforceable. For low enough $\delta$, both constraints bind and so both quintities are below the efficient level, with traded quantities of both goods continuously increasing in $\delta$.

Exchange with Money. Suppose now that the firm allows the divisions to trade among themselves using monetary transfers. Money has two features that fundamentally affect the set of attainal)le trades. First, money is always valued by the divisions and so becomes a source of payment for services. Second, money can be exchanged for the contractible good simultaneously, thus enforcing tracles on $q_{k}$. In terms of the relevant incentive compatibility constraints, this implies three effects of money. First, efficient trade always takes place on the contractible good, $q_{k}=q^{e f f}=1$, as there are no enforcement problems when money can be exchanged immediately upon delivery. Second, punishments are less severe as failure to cooperate can only be met with a dissolution of the partnership on the noncontractible good; trade always continues at its efficient level on the contractible good. ${ }^{21}$ As

\footnotetext{
${ }^{21}$ We take the position that trade on the contractible good is efficient on- and off-the-equilibrium-path because we see the repeated game we study as a metaphor for a world where information is collected on the "type" of a trading
} 
a consequence, the introduction of money has a deleterious effect by reducing credible punishments. Third, and more subtle, the introduction of money directly affects trade on the non-contractible good. This occurs even though the non-contractible goods cannot be verified by anyone outside the relationship and it is not known that service has been provided until after its delivery. The reason for this is that money can be offered as a voluntary gift when quality has been observed.

It turns out that the (weakly) optimal voluntary gift of money is equal to half the costs of production. This serves to relax incentive compatibility constraints most. ${ }^{22}$ Since the costs of production then effectively become half the costs incurred, this makes non-contractible trades easier to enforce. However, dishonesty on good $n$ cannot be penalized from exclusion from trade on good $k$ so the net gain from honesty is future trade only on the non-contractibles. The net effect is that the incentive compatibility constraint becomes:

$$
\frac{\lambda_{n}}{r} v\left(q_{n}\right)-\frac{c\left(q_{n}\right)}{2} \geq 0
$$

The guestion the'n remains as to whether the net effect of money on the economy is beneficial or not. If $\lambda_{k}>\lambda_{1}$. this constraint is more difficult to satisfy than our previous non-monetary constraint. This: in llue cust of using money in this section. In our paper, Prendergast and Stole [1995], we show that the hemefits of money depend on the discount rate in a simple non-monotonic fashion. If the cliscomnt rate is is sufficiently low, money trades should be allowed for the reason that little could br mbercel though reciprocity. However, an intermediate range of discount rates, money harms wellitw werlucing the costs of deviation. Therefore by making prices more "market determined", agurroatc arale falls. For moderately infrequent trade, the value of enforcing trades on good $k$ is cutweigher by the costs in terms of enforcing good $n$. This range of discount factors has strictly pusitive length if $\lambda_{k}>\lambda_{n}$. For large enough $\delta$, the policies of the firm are irrelevant as the first best

pirtner. where failure to reciprocate illustrates a lack of trustworthiness. In this world, it is only credible to exclude a devialor from non-contractible trades.

22 Remember that because money gifts are voluntary, such transfers are also governed by the standard incentives to renege that occur with goods transfers. Let $t$ be the equilibrium transfer made by an individual immediately after receiving the equilibrium transfer of $q_{n}$. There are now two relevant incentive compatibility constraints analogous to our previous single non-monetary constraint:

$$
\frac{\lambda_{n}}{r} v\left(q_{n}\right) \geq c\left(q_{n}\right)-t
$$

for the provider of the good, and

$$
\frac{\lambda_{n}}{r} v\left(q_{n}\right) \geq t
$$

for the donor of the voluntary transfer. These constraints are relaxed most at $t=\frac{1}{2} c\left(q_{n}\right)$, as both bind equally. 
can be attained under either regime.

For an illustrative case consider the setting in which $\lambda_{k}=\frac{1}{4}$ and $\lambda_{n}=\frac{1}{20}$ in Figure 3. The solid curves give equilibrium outcomes when monetary trade is banned and the dashed lines give similar information with money transfers.

The quantities traded are given in the bottom half while welfare is plotted in the top graph. The superscript $m$ refers to the monetary equilibrium, while no superscript refers to the case with money transfers banned. Without money, both goods are traded at equal levels and converge to $q_{i}=1$ as $\delta$ increases. With money transfers, good $k$ is traded at its first best level of 1 while trade in good $n$ is (weakly) lower than without money due to the absence of multi-market contact. Welfare in the top part of the Figure is given by $V^{m}$, and the difference between the two is given by the partial line, illustrating the non-monotonic effect of money in the discount rate, where greatest benefits of money accrue for low discount rates. ${ }^{23}$

Remark: The previous analysis provides an argument for a principal banning the use of money by its clivisions. The reader may find it odd that a firm should have at its disposable the ability to prohilit monetary trades everywhere - both on and off the equilibrium path - while we did not assume such commitment powers on the part of the individual players. One plausible reason the firm may have more commitment is that multiple versions of the above bilateral partnership may exist throughout the firm. Thus, if a division or employee in one of the partnerships decides to cheat and thereby start a punishment phase, the firm has an incentive to continue its policy of non-monetary tracling on the punishment path, so as to deter other bilateral partnerships from cheating. Thus, the corporation may want to create a reputation for itself, as has been argued elsewhere (see Kreps [1990]).

\footnotetext{
${ }^{23}$ The ambiguous effects of money arise from the fact that it has effects both on and off the equilibrium path. The idea that adding strategies must be evaluated on and off the equilibrium path arises from related work on multi-market contact by Bernheim and Whinston [1990] who note that the addition of another market on which to punish a deviator will typically increase the amount of feasible collusion. See also Baker, Gibbons, and Murphy [1994, 1996], Schmidt and Schnitzer [1995] and Bernheim and Whinston [1994]. Finally, closest in spirit to this analysis is Kranton [1995] who considers the role of money in enforcing trades, though her interest in it whether non-monetary trade is self-enforcing rather than on evaluating welfare effects.
} 


\subsubsection{Transfer Pricing}

Although some firms will sometimes find it optimal to ban all monetary transactions between employees or divisions as our previous argument suggests, in other firms in which the central authorities have more control over trades than simply allowing or banning all monetary transfers, something less drastic is preferable. These firms may design transfer pricing rules to regulate the trades that occur between the two divisions. The purpose of this subsection is to consider briefly the role of transfer pricing in our setting above. ${ }^{24}$ In our mathematical treatment of this problem in Prendergast and Stole [1996a], we allow the firm to attach a price of $p$ for every unit of good $q_{k}$ that is provided by a division. Note that the non-contractible good cannot be verified so that it is impossible to charge a price for $q_{n}$. The relevant question then becomes the choice of the optimal transfer price: does the firm choose to set transfer prices for the contractible good at the efficient level? This represents a natural generalization of the results above. We shcw two results. First, the firm never chooses transfer prices to compensate fully the provider of the service. In other words, firms always use non-1nonctary reciprocation of some degree to allocate contractible resources within its boundaries. The reason for this is that the firm would like to use the threat of withholding some trade on the (ontractil)le good as a means of inducing honesty on the non-contractible good, and it cannot do so if it serts a transfer price that fully compensates for good $k$. The second observation that arises is tlat firms will sometimes choose transfer prices of zero even in cases where first best trade cannot wrur. In ot lier words, beyond some point trade is always done completely by non-monetary reciprocilion. Therefore, even in a more continuous setting, the firm prefers to force all trades to be done ly wirhout money:

\subsection{Non-Monetary, Relationship-Specific Expenditures}

Non-nllnetary trade has at its essence the notion that agents pay for 'goods' using a means other than money. This section continues our interest in the role of trade sanctions by considering how relationships form and the means by which agents (e.g., employees, divisions, or separate firms) are allowed to access relationships. In other words, how do agents pay to join relationships? We adclress this issue in the context of posting bonds. A recurring theme in the economics literature is that repeated interaction can be facilitated by the posting of reputational bonds or "hostages"

\footnotetext{
${ }^{24}$ Measured transfers within firms are of enormous magnitude. For example, Mehafdi's [1990] study of 33 multinational British companies found that 21 percent had internally "priced" transfers valued at 10-25 percent of corporate sales, and 24 percent had internal transfers valued at over 25 percent of sales.
} 
to raise the costs to deviant behavior. ${ }^{25}$ In this section, we further explore this idea of making investments as a method of facilitating greater cooperation. In particular, we explore the usefulness and limitations of trade-enhancing "hostages." The purpose of this section is to show that money may be a particularly bad currency with which to attempt to gain admission to the relationship. We illustrate this by considering the role of an ideal hostage, which is something that has value only to the original owner and is valueless to all others. In this sense, giving a hostage to join a relationship must generally be a non-monetary transaction.

A Simple Model of Hostage Exchange Consider again our repeated interaction model of exchange from section 4.1.1. Suppose for simplicity that there is only one good which is noncontractible, $q_{n}$, and the model is otherwise unchanged. If $r$ is sufficiently small such that first-best exchange cannot be supported, there may be a role for relationship-specific expenditures to improve matters. In particular, let's amend our current game with an initial stage that allows each party to simultaneously choose whether or not to invest $H$ dollars in assets which satisfy three conditions:

1. the availability of one party's asset is controlled by the other party;

2. the assets are non-salvageable; and

3. the assets are non-tradeable amongst the parties.

In order to ignore productive efficiency questions, we will assume that each investment generates $r H$ dollars per period of time to the party that buys the asset, providing that the other party acquiesces to the payout of this return. That is, the other party has some control right over the bond which (an be used to destroy its value to the investing party.

Now consider the following equilibrium. If both trading partners invest in their respective bonds, the partners play the surplus-maximizing subgame equilibrium from our model in section 4.1.1. Specifically, they exchange $q_{n}$ at the most efficient level satisfying the incentive compatibility condition:

$$
\frac{\lambda_{n}}{r}\left(q_{n}-\frac{1}{2} q_{n}^{2}\right)+H \geq \frac{1}{2} q_{n}^{2}
$$

If either trading partner fails to invest in the appropriate asset, or if at anytime during the trading subgame either partner fails to provide $q_{n}$ when an opportunity arises, neither party trades again.

\footnotetext{
${ }^{25}$ Notable important papers in this vein include Telser [1980], Klein and Leffler [1981] and Williamson [1983,1984]. Klein and Leffler [1981] argue, for example, that the loss of brand name capital or non-salvageable productive assets by a firm who offers low quality products can be a sufficient deterrent so as to guarantee high quality on the marketplace. Williamson $[1983,1984]$ adds additional insights in his analysis of "hostages".
} 
Given our assumptions regarding the relationship-specific expenditures, this means that the value to the assets are lost forever. Because we have assumed that the investments are productively neutral, $H$ appears only on the left-hand side of the incentive compatibility condition, improving the ability of the partners to trade efficiently. From the above analysis, the value of such investments is clear.

Importantly, conditions (2) and (3) above regarding the specificity of the investments are necessary for cooperation to be enhanced. If, for example, assets were individually salvageable, the deviator can take the other's hostage, which will make deviation more desirable. Similarly, if the assets are tradeable between the parties, then $H$ disappears entirely from the incentive compatibility condition as the agents will swap their hostages at no cost following a deviation. This need for non-salvageability and non-tradeability of hostages implies that the hostages must be non-monetary.

An example of such investments has been noted by Hennart [1989]. Consider a repeated interaction between two firms - one Western and the other from a centrally-planned economy. The Western firm may invest in CPE-firm-specific marketing channels while the CPE-firm invests in Western-firm-specific plant and equipment. Thus, if the relationship deteriorates, the Western firm loses its investments marketing the CPE firm's consumer goods and the CPE firm loses ongoing service and spare parts of its Western-made plant. Note that because of difficulty enforcing hardto-verify exchanges (such as quality of marketing or plant service) across these national boundaries, in the crent of cheating by one party, it is unlikely that the investments can be efficiently transferred are completely salvaged. Thus, the investments strengthen the firms' ability to cooperate on non-contractible dimensions.

\section{Conclusion}

This essay is meant to be little more than exploratory. As we have mentioned throughout the paper, economists are fond of extolling the virtues of money over more barter-like arrangements, but firms and individuals continue to use non-monetary arrangements to an enormous degree. There has been little work that has systematically addressed this issue, only some scattered results in different literatures on this issue. The purpose of this paper has been to understand some of the themes that generate non-monetary trade as an optimal mechanism, and to evaluate these in the light of existing empirical work. 


\section{References}

Adams, William and Janet Yellen, 1976, "Commodity Bundling and the Burden of Monopoly," Quarterly Journal of Economics, August 1976, Vol. 90(3), 475-93.

Baker, George, Robert Gibbons and Kevin J. Murphy, "Subjective Performance Measures in Optimal Incentive Contracts," Quarterly Journal of Economics, November 1994, Vol. 109, 1125-1156.

Baker, George, Robert Gibbons and Kevin J. Murphy, 1996, "Implicit Contracts and the Theory of the Firm," mimeo, April 1996.

Banks, Gary, 1985, "Constrained Markets, 'Surplus' Commodities and International Barter," Kyklos, Vol. 38(2), 249-267.

Bernheim, Douglas and Michael Whinston, 1990, "Multimarket Contact and Collusive Behavior," Rand Journal of Economics, Spring 1990, Vol. 21(1), 1-26.

Bernheim, Douglas and Michael Whinston, 1994, "Incomplete Contracts and Strategic Ambiguity," mimeo, September 1994.

Bolton, Patrick and Joseph Farrell, 1990, "Decentralization, Duplication, and Delay," Journal of Political Economy, Vol. 98(4), 803-826.

Bork, Robert, 1978, The Antitrust Paradox: A Policy at War with Itself, New York: Free Press.

Bussard, Willis, 1987, "An Overview on Countertrade Practices of Corporations and Individual Nations, "in Christopher M. Korth, ed., International Countertrade, New York: Quorum, pp. $13-25$.

Carlton, Dennis and Jeffrey Perloff, 1994, Modern Industrial Organization, Second Edition, Harper Collins Publishers.

Carter, J. and J. Gagne, 1988, "The Do's and Dont's of International Countertrade", Sloan Management Review, Vol. 29, 31-37.

Caves, Richard, 1974, "The Economics of Reciprocity: Theory and Evidence on Bilateral Trading Agreements." in W. Sellekaerts (Ed.), International Trade and Finance, London: Macmillan.

Caves, Richard and Dalia Marin, 1992 "Countertrade Transactions: Theory and Evidence," Economic Journal, September 1992, Vol. 102, 1171-1183.

Ellingsen, Tore and Lars Stole, 1996, "Mandated Countertrade as Strategic Commitment," Journal of International Economics, Vol. 40, No. 1, February 1996, 67-84.

Hennart, Jean-Francois, 1989, "The Transaction-Cost Rationale for Countertrade", Journal of Law, Economics \& Organization, Spring 1989, Vol. 5(1), 127-153.

Hennart, Jean-Francois and Erin Anderson, 1993, "Countertrade and the Minimization of Transaction Costs: An Empirical Examination," Journal of Law, Economics \& Organization, Vol. $9(2), 290-313$.

Hirshleifer, Jack, 1995, "Anarchy and its Breakdown," Journal of Political Economy, February 1995, Vol. 103(1), 26-52. 
International Reciprocal Trade Association, 1995, IRTA 1995 Reciprocal Trade Fact Sheets, http: //www. dgsys . com.

Jevons, Stanley, 1875, Money and the Mechanism of Exchange, London: Keegan, Paul, Trench, Trubner, reprinted 1923.

Klein, Benjamin, and Keith Leffler, 1981, "The Role of Market Forces in Assuring Contractual Performance," Journal of Political Economy, Vol. 89(4), 615-641.

Kogut, Bruce, 1986, "On Designing Contracts to Guarantee Enforceability: Theory and Evidence from East-West Trade," Journal of International Business Studies, Spring 1986, Vol. 17(1), pp. $47-62$.

Kranton, Rachel, 1995, "Reciprocal Exchange: A Self-sustaining System," mimeo, March 1995.

Kreps, David, "Corporate Culture and Economic Theory," in James E. Alt and Kenneth A. Shepsle. eds., Perspectives on Positive Political Economy. Cambridge, England, Cambridge University Press, 1990, pp. 90-143.

Marin. Dalia, 1990, "Tying in International Trade," World Economy, September 1990, Vol. 13(3), [)] $445-462$.

Marin, Dalia and Monika Schnitzer, 1995, "Tying trade Flows: A Theory of Countertrade witlı Eviclence." American Economic Review, December 1995, Vol. 85(5), 1047-1064.

Masten. Scott and Edward Snyder, 1993, "United States v. United Shoe Machinery Corporatum: ()n the Merits," Journal of Law and Economics, April 1993, Vol. 36, pp. 33-70.

McAfee. Preston, John McMillan and Michael Whinston, 1989, "Multiproduct Monopoly, (ommuclity Bundling, and Correlation of Values," Quarterly Journal of Economics, May 1989, (i) $104(2), 371-83$.

Mehafdi. Messaoud, 1990, "Behavioural Aspects of Transfer Pricing in U.K. Decentralized Compriniu's." unjul)lished Ph.D. dissertation, Thames Polytechnic, London (with the collaboration of Cilitigow University).

Milgrom, Paul and Roberts, John, 1992, Economics of Organization and Management, Englewoocl Cliffs, New Jersey: Prentice Hall, Inc.

Mirus, Rolf and Bernard Yeung, 1986, "Economic Incentives for Countertrade," Journal of Iniemational Business Studies, Fall 1986, pp. 27-39.

Prendergast, Canice and Lars Stole, 1992, "Favors and Gifts," mimeo, May 1992.

Prendergast, Canice and Lars Stole, 1995, "Monetizing Social Exchange," mimeo, December 1995.

Prendergast, Canice and Lars Stole, 1996a, "Economic Theories of Inter- and Intra-firm Nonmonetary Exchange," mimeo, May 1996.

Prendergast, Canice and Lars Stole, 1996b, "The Simple Economics of Barter Exchanges," mimeo, June 1996. 
Prendergast, Canice and Lars Stole, 1996c, "The Use Of Money in Social Situations," mimeo, June 1996.

Rajan, Raghuram and Luigi Zingales, 1995, "The Tyranny of the Inefficient: An Enquiry into the Adverse Consequences of Power Struggles," mimeo, December 1995.

Roha, Ronaleen and Marc Schulhof, 1996, "How Bartering Saves Cash," Kiplinger's Personal Finance Magazine, February 1996, Vol. 50(2), pp. 103-104.

Schmidt, Klaus and Monika Schnitzer, 1995, "The Interaction of Explicit and Implicit Contracts," Economics Letters, May 1995, Vol. 48(2), 193-99.

Skaperdas, Stergios, 1992, "Cooperation, Conflict, and Power in the Absence of Property Rights," American Economic Review, September 1992, Vol. 82(4), 720-739.

Sloane, L., 1961, "Reciprocity: Where Does the P.A. Stand?," Purchasing, 51, 70-79.

Stigler, George, 1969, "Reciprocity," Working Paper IV, Nixon Task Force on Productivity and Competition. February 18, 1969, reproduced in Antitrust Law \& Economics Review, Spring 1969.

Telser, Lester, 1980, "A Theory of Self-Enforcing Agreements," Journal of Business, February 1981, Vol. 53, $27-44$.

Tirole, Jean, 1988, The Theory of Industrial Organization, Cambridge, Mass.: MIT Press.

Weitzman, Martin, 1974, "Prices versus Quantities," Review of Economic Studies, October 1974, Vol. 41, 47T-91.

Williamson, Oliver, 1983, "Credible Commitments: Using Hostages to Support Exchange," American Economic Review, September 1983, Vol. 73(4), 519-540.

Williamson, Oliver, 1984, "Credible Commitments: Further Remarks," American Economic Review, June 1984, Vol. 74(3), 488-490. 
Figure 1. The Net Benefit to Barter Exchange.

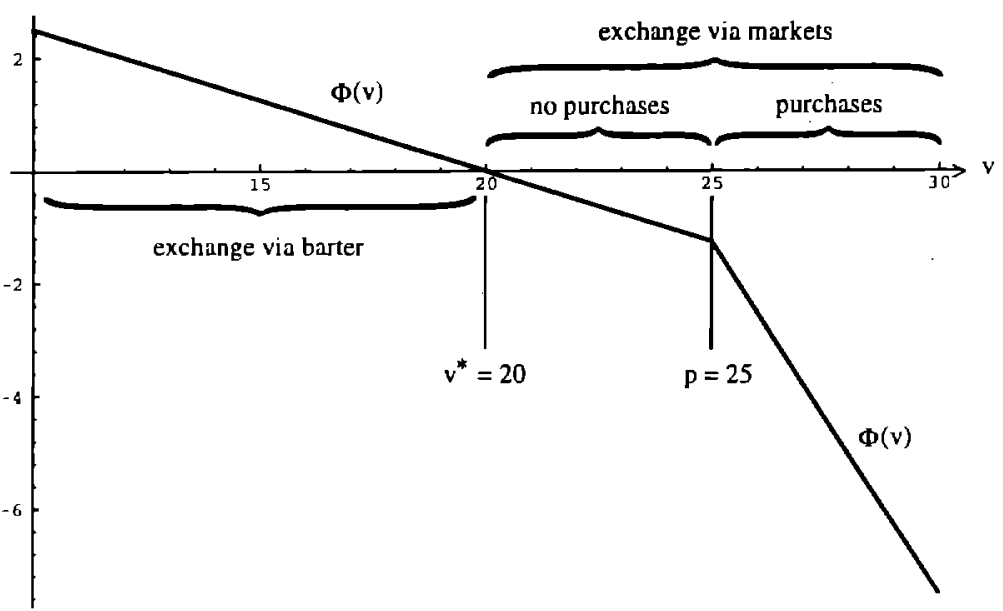


Figure 2. Bilateral Monopoly versus Barter
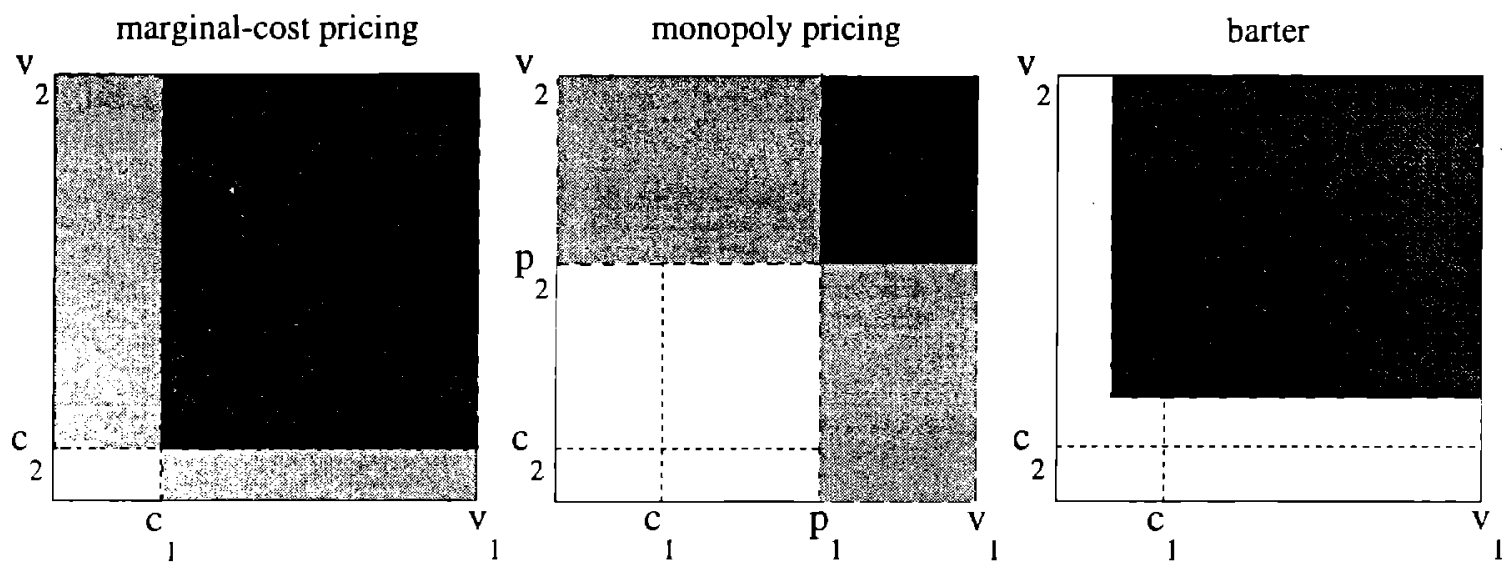
Figure 3. The Effect of Monetizing Dynamic Trading Relationships
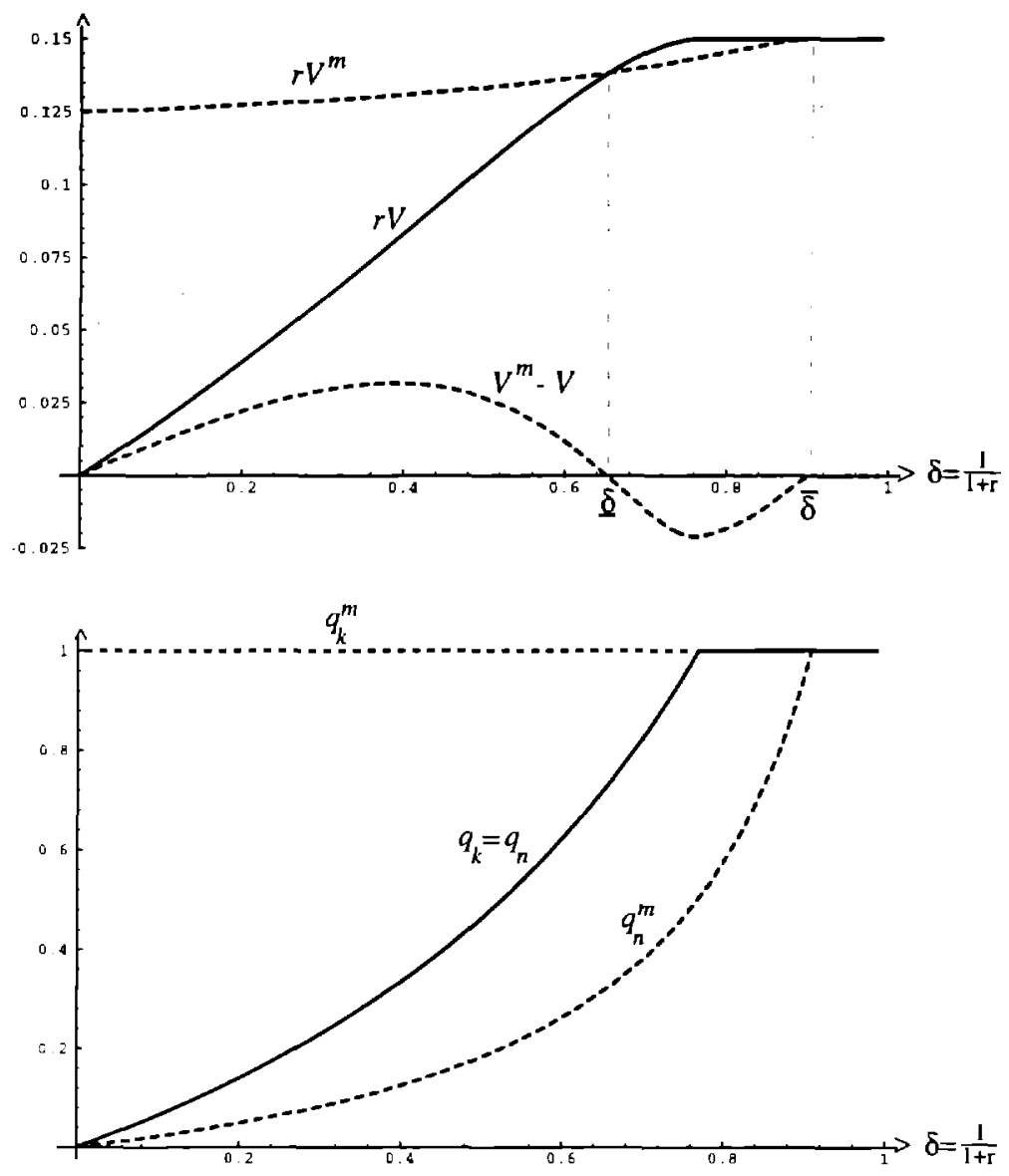